\title{
Effects of Cadmium Stress on Antioxidant Enzymes and Osmolyte Accumulation in Aromatic Rice Seedlings
}

\author{
Adam ShekaKanu ${ }^{1,2,3}$, UmairAshraf ${ }^{1,2}$, Abdulai Bangura ${ }^{3}$, RenYong ${ }^{1,2}$, \\ Kong Lei-lei ${ }^{1,2}$, IssakaFuseini ${ }^{4}$, Dong Hai ${ }^{1,2}$, MeiyangDuan ${ }^{1,2}$, XiangruTang ${ }^{1,2}$ \\ ${ }^{I}$ Department of Crop science and Technology, College of Agriculture, South China Agricultural University, \\ Guangzhou 510642, China; \\ ${ }^{2}$ Scientific Observing and Experimental Station of Crop cultivation in South China, Ministry of Agriculture P. R. \\ China, Guangzhou, 510642 PR China \\ ${ }^{3}$ Sierra Leone Agricultural Research Institute (SLARI)-Rokupr Agricultural Research Centre (RARC), PMB \\ 1313, Freetown Sierra Leone \\ ${ }^{4}$ Department of Environmental Science and Engineering, South China Agricultural University, College of \\ Natural Resource and Environment, Guangzhou China
}

\begin{abstract}
Cadmium $(C d)$ has been proven to affect plant growth and development. Experiment was therefore, conducted to examine the influence of $\mathrm{Cd}$ on aromatic rice cultivars at tillering stage. The experiment was arranged in a randomized complete block design comprising three different aromatic rice cultivars (Meixiangzhan 2, Xiangyaxiangzhan and Guixiangzhan) and three Cd levels $\left(0,50\right.$ and $100 \mathrm{mg} / \mathrm{kg}^{-1}$ soil). Antioxidant enzymes (Superoxide dismutase (SOD), Peroxidase(POD), and Catalase(CAT)), osmolyte accumulation (proline, protein, total sugar, amino acid), lipid peroxidation (in terms of melanodialdehyde(MDA)) and growth parameters (plant height, and total dry matter content) and Cd uptake in rice cultivars exposed to different Cd levels were examined. The results showed that, with increased levels of soil Cd toxicity, activities of SOD and MDA contents increased, while activities of POD and CAT enzymes, as well as osmolyte accumulation and dry matter contents decreased for all cultivars. Cd uptake in roots and in shoots of all the cultivars increased with increased soil Cd contents. Uptake was higher in roots than in shoots with Meixiangzhan 2 showing the highest uptake in both roots and shoots followed by Xiangyaxiangzhan and Guixiangzhan cultivars. The results suggested that soil Cd toxicity have negative consequences on rice growth. Rice roots accumulated higher $C d$ than shoots and uptake varies amongst cultivars. Conclusively, Cd toxicity impaired early growth in rice by affecting physio-biochemical attributes, however, Guixiangzhan variety performed better than the other two varieties.
\end{abstract}

Key Words; Cadmium effects, Rice, Uptake, Antioxidants Enzymes, Osmulyte accumulation

\section{Introduction}

Rice production is being altered by a number of abiotic stresses including heavy metals. Cadmium is among the most toxic heavy metals deposited in agricultural soilsthrough natural and anthropogenic means like; the application of sewage sludge containing $\mathrm{Cd}$ contents, phosphate fertilizers application and other waste disposal as well as metal smelting (Rizwan et al. 2012; Douay et al. 2009). Cd toxicity in agricultural soils is a serious threat to crop production worldwide (Rizwan et al., 2016). Even in low concentration, Cd becomes highly toxic to both growing plant as well as animalsdue to its non-essential form in living organisms, and thus affects rice seedlings morphologically, physiologically and biochemically during growth. Song et al. (2015) reported that $\mathrm{Cd}$ can be taken up by rice roots and then translocated to shoots and grains of growing rice. The most common visible symptoms of $\mathrm{Cd}$ toxicity in growing rice plants are; retardation of plant growth, chlorosis andeventually plant death.

High Cd accumulation in rice consumed by animals especially humans, has several health implications such as cardiac failure, anaemia, cancer, hypertension, emphysema, proteinuria, cerebrovascular infarction, damage to the lungs, renal dysfunction in eyes, and osteoporosis (Ashraf et al., 2015; Sebastian and Prasad., 2015). Cd translocation from soil to shoot and finally to the edible parts of rice(grains) is the easiest pathway by which increasing Cd exposure opportunity to human beings is catalysed (Römkens et al . 2009). Research has shown that, nearly sixteen percent $(16 \%)$ of the agricultural soils in China have been polluted by varying heavy metals, of these, approximately $1.3 \times 105 \mathrm{hm}^{2}$ of these soils have been polluted by varying degrees of $\mathrm{Cd}$, and agricultural products polluted by Cd resulting to $1.46 \times 108 \mathrm{~kg}$, including 50000 tons of rice (Xu et al. 2014).

Rice (Oryzasativa L.), is a major cereal crop cultivated and consumed worldwide, it's the second most important cereal crop after wheat in terms of area cultivated and consumption rate. Due to the level of importance attached to rice, it therefore, becomes eminent to understand how different aromatic rice cultivars 
perform under varying levels of cadmium toxicity. Rice growth and development is most eminent during the vegetative growth stage where seedlings development is initiated. Rice growth at tillering stage comprises roots development for nutrients uptake,hypocotyl elongationand enzymes activation for mobilizing stored energy and nutrients as well as photosynthetic processes. Cd stress has been proven to have some morpho-physiological and antioxidants effects in rice seedlings at the early growth stage (vegetative stage) especially in paddy polluted soils. Reports have shown reduction in rice growth and biomass, which might possibly be as a result of different Cd-mediated toxicity mechanisms in rice (Srivastava et al. 2014). Other studies have reported that the toxic effects of $\mathrm{Cd}$ increased rice seedlings oxidative stress by releasing reactive oxygen species (ROS) like malondialdehyde (MDA) contents, hydrogen peroxide $\left(\mathrm{H}_{2} \mathrm{O}_{2}\right)$ and electrolyte leakage which affects rice growth and performance( $\mathrm{Yu}$ et al. 2013; Srivastava et al. 2014). Cadmium toxicity also altered leaf and root ultrastructure and caused structural damages to photosynthetic apparatus of rice.

From several other studies conducted, marked differences in Cd uptake and translocation among plant species as well as among cultivars within the same species were observed (Liu et al. 2007; Grant et al. 2008; Sebastian and Prasad, 2015).

Most research conducted mainly focused on rice performance at maturity when subject to $\mathrm{Cd}$ stress conditions, little is known regarding different aromatic rice genotypes performances at tillerering stage when grown under cadmium toxic soils. This study looked at variation of $\mathrm{Cd}$ uptake in scented rice roots and translocation to straws as wellas activities ofantioxidantenzymes, osmolyte accumulation and growth parameters during the vegetative stage in rice subjected to $\mathrm{Cd}$ stressed conditions. The results will serve useful purposes for understanding the performance of different aromatic rice cultivars under varying cadmium stress.

\section{Soil Preparation and Pot Experiment}

\section{Research Design}

Pot experiment was conducted in rain protected greenhouse under open-air conditions at the experimental research farm (College of Agriculture, South China Agricultural University (SCAU)), Guangzhou city $\left(23^{\circ} 14^{\prime} \mathrm{N}, 113^{\circ} 37^{\prime} \mathrm{E}, 20 \mathrm{M}\right.$ altitude) during $2015 / 2016$ cropping years. The pots were arranged in a two Factor Factorial Experiment with Completely Randomized Design, each treatment replicated three times. Paddy soil from the research farm was collected to a depth of $20 \mathrm{~cm}$ and then air dried, after air-drying, the paddy soil was grinned and sieved through a $4 \mathrm{~mm}$ sieve, mixed thoroughly and filled in the pots $(25 \mathrm{~cm}$ diameter by 30 $\mathrm{cm}$ height). About 10 kilograms of soil was filled in each pot and $\mathrm{Cd}$ in the form of $\mathrm{CdCl}_{2} .21 / 2 \mathrm{H}_{2} \mathrm{O}$ was added to the soil to obtain the following Cd levels as: a control with no added $\mathrm{Cd}(\mathrm{Cd} 0), 50 \mathrm{mg} \mathrm{Cd} / \mathrm{kg}$ of soil added $(\mathrm{Cd} 1)$, and $100 \mathrm{mg} \mathrm{Cd} / \mathrm{kg}$ of soil added $(\mathrm{Cd} 2)$. The pots once filled with soil were thoroughly mixed with the exact amount of $\mathrm{Cd}\left(\mathrm{CdCl}_{2} .21 / 2 \mathrm{H}_{2} \mathrm{O}\right)$ based on the treatment and kept for 15 days before the rice seedlings were transplanted in them. Soil used for the experiment was analyzed before use and was found to contain 4.96 $\mathrm{mg} / \mathrm{kg}$ Cd content, $5.92 \mathrm{pH}$ level, $18.73 \mathrm{~g} / \mathrm{kg}$ organic matter contents, while total NPK was $0.81,0.9$ and 16.79 $\mathrm{g} / \mathrm{kg}$, and available NPK 69.15, 10.15 and $109.62 \mathrm{mg} / \mathrm{kg}$ respectively.

\section{Rice Cultivars Preparation}

Three aromatic rice varieties, Meixiangzhan 2, Xiangyaxiangzhan, and Guixiangzhan, were secured from the Department of Crop Science and Technology, College of Agriculture, South China Agricultural University (SCAU)), Guangzhou. Rice seeds were first soaked in deionized water for about $48 \mathrm{hrs}$. at room temperature $\left(20-25^{\circ} \mathrm{C}\right)$ and later nursed on March 3rd, 2015 in uncontaminated soil using parachute trays under moist conditions. After 15 days $\left(29^{\text {th }}\right.$ March, 2015), the seedlings were transplanted into the pots (4 seedlings per pot). The pots were maintained under flooded conditions of about 2-3 cm water level above the soil surface during the whole vegetative growth period. Required rates of fertilizers were split applied as basal fertilizer and during the growth period after transplanted seedlings had maintained growth stability. Entire rice was harvested and samples collected after six weeks. The samples were separated in to fresh samples stored in refrigerators at required temperatures for enzymes analysis, while the other set was oven dried at $80^{\circ} \mathrm{C}$ for analysis of plants biomass accumulation and $\mathrm{Cd}$ uptake in straw and root.Antioxidant enzymes (superoxide dismutase (SOD), Peroxidase (POD), Catalase (CAT)) and Malondialdehyde (MDA) Detection.

Enzymes were extracted following Cho and Seo (2005) method. In which rice straw were homogenised using a mortar and pestle with a $0.05 \mathrm{M}$ sodium phosphate buffer of $\mathrm{pH} 7.5$ containing $\mathrm{Mm}$ ethylenediaminetetraacetic acid (EDTA) and 1\% polivynilpyrrolidone (PVP). The homogenate was centrifuge at $12,000 \mathrm{~g}$ for 15 minutes and the supernatant was stored at $40 \mathrm{c}$ and later used to determine SOD, POD and CAT. SOD

SOD activity was determined following Zhou et. al., (2003) with slight modification. The reaction mixture containing $81 \mathrm{~mL}$ of $14.5 \mathrm{mM}$ methionine, $3 \mathrm{~mL}$ of $2.25 \mathrm{mMnitrobluetetrazolium} \mathrm{chloride} \mathrm{(NBT),} 3 \mathrm{~mL}$ of $3 \mu \mathrm{M}$ EDTA- $\mathrm{Na}_{2}$ and $3 \mathrm{~mL}$ of $60 \mu \mathrm{M}$ riboflavin, was prepared with a $0.05 \mathrm{M}$ sodium phosphate buffer $(\mathrm{pH}$ 7.8) with the exception of riboflavin which was prepared using deionized water. $50 \mu \mathrm{L}$ enzyme extract was 
added to the tubes containing $3 \mathrm{~mL}$ of the reaction mixtures. The mixtures in the tubes were then exposed to illumination incubator for duration of $20 \mathrm{~min}$ with one kept in the dark to serve as control. The absorbance was recorded using a spectrophotometer at $560 \mathrm{~nm}$. One unit of SOD enzyme activity was defined as the quantity of SOD required to produce 50\% reduction of NBT under experimental conditions and the specific enzyme activity expressed in units per $\mathrm{g}$ leaves fresh weight (FW).

\section{POD assay}

POD activity was detected following the procedure of Xu et al., (2008), reaction mixtures containing $75 \mathrm{~mL}$ of $100 \mathrm{mM}$ sodium phosphate buffer $(\mathrm{pH} 6.0), 28.5 \mu \mathrm{L} \mathrm{H}_{2} \mathrm{O}_{2}(30 \%)$ and $42 \mu$ Lguaiacol, were prepared just before use. $1 \mathrm{~mL}$ enzyme extract then added to the $3 \mathrm{~mL}$ reaction mixtures. The increasing absorbance was measured at $470 \mathrm{~nm}$ at 1 min intervals up to 3 min using spectrophotometer. One unit of POD enzyme activity was defined as absorbance changes at $470 \mathrm{~nm}$ per minute. Enzyme specific activity was expressed as units per $\mathrm{g}$ FW.

\section{CAT assay}

CAT activity was determined using a spectrophotometer following $\mathrm{Xu}$ et al., 2008, in which the reaction mixture containing $1.5 \mathrm{~mL}$ of $0.05 \mathrm{M}$ sodium phosphate buffer $(\mathrm{pH} 7.8), 1 \mathrm{~mL}$ deionized water and 0.3 $\mathrm{mL}$ of $0.1 \mathrm{M} \mathrm{H}_{2} \mathrm{O}_{2}$ was prepared immediately before use, $0.2 \mathrm{~mL}$ enzyme extract was then added to the reaction solution. CAT activity was measured by monitoring the decrease in absorbance at $240 \mathrm{~nm}$ due to $\mathrm{H}_{2} \mathrm{O}_{2}$ consumption. One unit of CAT enzyme activity was defined as changes at $240 \mathrm{~nm}$ per minute. Enzyme specific activity was expressed as units per $\mathrm{g}$ FW.

\section{Lipid peroxidation}

Lipid peroxidation was expressed as malondialdehyde (MDA) content in $\mu \mathrm{M}$ per g $\mathrm{FW}$ following Zhang et al. (2005) with minor modifications. The fresh leaves were homogenized in $5 \mathrm{~mL}$ of $10 \%$ trichloroacetic acid (TCA) using a pestle and mortar. The homogenates were centrifuged at $4000 \mathrm{~g}$ for $10 \mathrm{~min}$. To each $2 \mathrm{~mL}$ aliquot of the supernatant, $2 \mathrm{~mL}$ of $0.6 \%$ thiobarbituric acid (TBA) in 10\% TCA was added. The mixture were heated at $100^{\circ} \mathrm{C}$ for $30 \mathrm{~min}$ and then cooled in an ice bath. The mixture was centrifuged at 10,000 $\mathrm{g}$ for $10 \mathrm{~min}$ and the absorbance of the supernatant recorded at $532 \mathrm{~nm}$ and $450 \mathrm{~nm}$.

Osmolyte contents detection (proline, protein, total sugar, amino acid)

\section{Estimation of free proline}

Proline was determined following Bates et al., $0.3 \mathrm{~g}$ of plant sample was homogenized in a $10 \mathrm{ml}$ of $3 \%$ aqueous sulphosalicylic acid. The homogenate was filtered using Whatmann No. 42 filter paper. $2 \mathrm{ml}$ of ninhydrin ( $1.25 \mathrm{~g}$ ninhydrin in $30 \mathrm{ml}$ of glacial acetic acid and $20 \mathrm{ml}$ of $6 \mathrm{M}$ phosphoric acid) and $2 \mathrm{ml}$ of glacial acetic acid in a test tube was heated for $30 \mathrm{~min}$ at $1000 \mathrm{C}$. The reaction mixture was then extracted with $4 \mathrm{ml}$ toluene and mixed vigorously by using a vortex mixture for $15-20 \mathrm{sec}$. The chromophore containing toluene was aspirated from the aqueous phase. The absorbance of the toluene layer was measured in a spectrophotometer at $520 \mathrm{~nm}$ using toluene as blank.

\section{Estimation of protein}

Protein content was determined following Lowry et al., (1951) with minor modifications. $0.3 \mathrm{~g}$ fresh samples were homogenized in $20 \%$ trichloroacetic acid using mortar and pestle. The homogenate was then centrifuged at $1200 \mathrm{rpm}$ for $15 \mathrm{~min}$ and the supernatant was discarded. Five $\mathrm{ml}$ of $0.1 \mathrm{~N} \mathrm{NaOH}$ was added to the pellet and it was centrifuged for $10 \mathrm{~min}$. The supernatant was saved for the estimation of protein. To $0.5 \mathrm{ml}$ of the extract, $5 \mathrm{ml}$ of copper reagent ' $\mathrm{C}$ ' was added (Reagent C: mixture of reagents A and B in the 50:1 ratio; Reagent A: $2 \% \mathrm{Na}_{2} \mathrm{CO}_{3}$ in $0.1 \mathrm{~N} \mathrm{NaOH}$; Reagent $\mathrm{B}$ : equal volume of $1 \% \mathrm{CuSO}_{4}$ and 2 per cent sodium potassium tartrate). The tubes were shaken well and allowed to stand in dark for $10 \mathrm{~min}$ at room temperature, $0.5 \mathrm{ml}$ of well diluted Folin-Ciocalteau reagent was added to the solution and mixed thoroughly. The absorbance was then taken at $500 \mathrm{~nm}$ in a photo spectrophotometer against an appropriate blank. Bovin serum albumin was used as the standard.

\section{Estimation of total sugars}

Total sugars were determined following Nelson's (1944) procedure. The process involves treating plant samples with $80 \%$ boiling ethanol for extraction, one $\mathrm{ml}$ of ethanol extract in the test tubes was evaporated in water bath. $1 \mathrm{ml}$ of distilled water and $1 \mathrm{ml}$ of $1 \mathrm{~N}$ sulphuric acid were then added and incubated at $49{ }^{\circ} \mathrm{C}$ for up to $30 \mathrm{~min}$. The solution was neutralised with $1 \mathrm{~N}$ sodium hydroxide using methyl red indicator. One $\mathrm{ml}$ of Nelson's reagent was added to each test tube prepared by mixing reagent A and reagent B in 25:1 ratio (Reagent A: $25 \mathrm{~g}$ sodium carbonate, $25 \mathrm{~g}$ sodium potassium tartarate, $20 \mathrm{~g}$ sodium bicarbonate and $200 \mathrm{~g}$ anhydrous 
sodium sulphate in $1000 \mathrm{ml}$; Reagent B: $15 \mathrm{~g}$ cupric sulphate in $100 \mathrm{ml}$ of distilled water with 2 drops of concentrated sulphuric acid). The test tubes were then heated for $20 \mathrm{~min}$ in a boiling water bath, the mixture was then allowed to cooled down and $1 \mathrm{ml}$ of arsenomolybdate reagent $(25 \mathrm{~g}$ ammonium molybdate, $21 \mathrm{ml}$ concentrated sulphuric acid, $5 \mathrm{~g}$ sodium arsenate dissolved in $475 \mathrm{ml}$ of distilled water and incubated at $37^{\circ} \mathrm{C}$ in a water bath for $48 \mathrm{~h}$ ) was added. The solution was thoroughly mixed and diluted to $25 \mathrm{ml}$ and measured at 495 $\mathrm{nm}$ in a spectrophotometer. The reducing sugar contents of unknown samples were then calculated from glucose standard.

\section{Estimation of amino acids}

Amino acids were determined following Moore and Stein (1948), $1 \mathrm{ml}$ ethanol extract was taken in 25 $\mathrm{ml}$ test tubes and neutralized with $0.1 \mathrm{~N}$ sodium hydroxide using methyl red indicator. $1 \mathrm{ml}$ of ninhydrin reagent was added (800 mg stannous chloride in $500 \mathrm{ml}$ citrate buffer, pH 5.0, $20 \mathrm{~g}$ ninhydrin in 500 ml methyl cellosolve,both solutions were mixed). The mixture was boiled in a water bath for $20 \mathrm{~min}, 5 \mathrm{ml}$ of diluent solution (distilled water and n- propanol mixed in equal volume) was added, then cooled down and diluted to $25 \mathrm{ml}$ with distilled water. The absorbance was measured at $570 \mathrm{~nm}$ using photo spectrophotometer. The standard graph was prepared using leucine.

Growth parameters detection (shoot length, root length, dry matter content)

Morphological parameters including root length, shoot length and dry matter contents per plant were determined for every treatment. Plant and root heights were measured using a ruler at harvest after 45 days growth period. Whereas, dry matter contents was determined by weighing 1 hill of oven dried rice samples and results expressed in $\mathrm{g} / \mathrm{hill}$.

\section{Cd uptake detection}

After oven drying, plant samples were then ground to powdered form and digested using concentrated $\mathrm{HNO}_{3}$ and $\mathrm{HClO}_{4}$ in an 8:2, V/V as suggested by Allen (1989). After digestion, Cd concentrations in the roots and straw were analysed using a flame atomic absorption spectrometer.

\section{Statistical analysis}

Data was analysed using Microsoft excel 2010 and Analysis of variance was performed using Statistix 8 (Analytical, Tallahassee, Florida, USA). The data were analysed by one-way analysis of variance to assess differences in parameters between treatments.

\section{Cadmium effects on biochemical content in rice leaves}

\section{Results}

Proline, protein, amino acid and total sugar contents in rice leaves were determined and results presented in table 1 . The contents of proline, protein, amino acid and total sugar were all found reducing with increased Cd toxic levels in the soil. There were significant differences in all the treatments for all cultivars. The leaves proline, protein, amino acid and total sugar contents were found maximum at the control treatment $(0 \mathrm{mg}$ $\mathrm{kg}^{-1}$ ) for all the cultivars, while the minimum contents were recorded at the $100 \mathrm{mg} \mathrm{kg}^{-1}$ soil level treatments for all cultivars. Guixiangzhan showed the highest proline, protein, amino acid and total sugar contents followed by Meixiangzhan 2 and the least on Xiangyaxiangzhan. There were34.68 and $62.68 \%$ for Meixiangzhan 2, 19.32 and $57.895 \%$ for Xiangyaxiangzhan and 14.81 and $39.81 \%$ decreasesfor Guixiangzhanin prolinecontents for both 50 and $100 \mathrm{mg} \mathrm{Cd} / \mathrm{kg}$ soil respectively when compared to the control treatment. For protein contents, the decreases were; 3.27 and 21.36\% in Meixiangzhan 2, 27.85 and $40.32 \%$ in Xiangyaxiangzhan and 0.71 and $6.42 \%$ in Guixiangzhan for both 50 and $100 \mathrm{mg} \mathrm{Cd} / \mathrm{kg}$ soil respectively when compared to the control treatment. For amino acid contents, there were 34.81 and $47.84 \%$ in Meixiangzhan 2, 38.52 and $61.59 \%$ in Xiangyaxiangzhan and 18.76 , and $24.95 \%$ in Guixiangzhan decreases for both 50 and $100 \mathrm{mg} \mathrm{Cd} / \mathrm{kg}$ soil respectively when compared to the control treatment. For total sugar contents, the decreases were 13.14 and $36.83 \%$ in Meixiangzhan 2, 8.22 and 36.46\% in Xiangyaxiangzhan and 10.43 and $19.39 \%$ in Guixiangzhan for both 50 and $100 \mathrm{mg} \mathrm{Cd} / \mathrm{kg}$ soil respectively when compared to the control treatment. This shows the extent of cultivar variation in response to rice biochemical contents under $\mathrm{Cd}$ toxicity.

Table 1. Cadmium effects on biochemical content in rice leaves

\begin{tabular}{|l|l|l|l|l|l|}
\hline Variety & $\begin{array}{l}\text { Treatm } \\
\text { ents }\end{array}$ & $\begin{array}{l}\text { Proline content } \\
(\mu \mathrm{g} / \mathrm{g})\end{array}$ & $\begin{array}{l}\text { Protein } \\
\text { content }(\mu \mathrm{g} / \mathrm{g})\end{array}$ & $\begin{array}{l}\text { Amino acid content } \\
(\mathrm{mg} / \mathrm{kg})\end{array}$ & $\begin{array}{l}\text { Total sugar content } \\
(\mathrm{mg} / \mathrm{kg})\end{array}$ \\
\hline Meixiangzhan 2 & $\mathrm{Cd} 0$ & $25.0 \mathrm{a}$ & $479.00 \mathrm{a}$ & $7.67 \mathrm{a}$ & $25.33 \mathrm{a}$ \\
\cline { 2 - 7 } & $\mathrm{Cd} 1 \mathrm{16.33 \textrm {b }}$ & $463.33 \mathrm{a}$ & $5.00 \mathrm{~b}$ & $22.00 \mathrm{~b}$ \\
\hline
\end{tabular}


Effects of Cadmium Stress on Antioxidants Enzymes and OsmolyteAccumulation in Aromatic Rice

\begin{tabular}{|l|l|l|l|l|l|}
\hline & $\mathrm{Cd} 2$ & $9.33 \mathrm{c}$ & $376.67 \mathrm{~b}$ & $4.00 \mathrm{~b}$ & $16.00 \mathrm{c}$ \\
\hline \multirow{5}{*}{ Xiangyaxiangzhan } & $\mathrm{Cd} 0$ & $19.0 \mathrm{a}$ & $403.33 \mathrm{a}$ & $8.67 \mathrm{a}$ & $28.33 \mathrm{a}$ \\
\cline { 2 - 7 } & $\mathrm{Cd} 1$ & $15.33 \mathrm{~b}$ & $291.00 \mathrm{~b}$ & $5.33 \mathrm{~b}$ & $26.00 \mathrm{~b}$ \\
\cline { 2 - 6 } & $\mathrm{Cd} 2$ & $8.00 \mathrm{c}$ & $240.67 \mathrm{c}$ & $3.33 \mathrm{c}$ & $18.00 \mathrm{c}$ \\
\hline \multirow{5}{*}{ Guixiangzhan } & $\mathrm{Cd} 0$ & $27.0 \mathrm{a}$ & $490.50 \mathrm{a}$ & $7.33 \mathrm{a}$ & $22.33 \mathrm{a}$ \\
\cline { 2 - 6 } & $\mathrm{Cd} 1$ & $23.0 \mathrm{ab}$ & $487.00 \mathrm{a}$ & $6.33 \mathrm{ab}$ & $20.00 \mathrm{ab}$ \\
\cline { 2 - 6 } & $\mathrm{Cd} 2$ & $16.25 \mathrm{~b}$ & $459.00 \mathrm{~b}$ & $5.00 \mathrm{~b}$ & $18.00 \mathrm{~b}$ \\
\hline
\end{tabular}

Means having different letters indicate significant differences at $\mathrm{p}<0.05$.

Cadmium effects on changes in antioxidant enzymes (SOD, POD, CAT) and MDA in rice roots and shoots

Changes in the activities of SOD, POD, CAT and MDA were observed in both roots and leaves for all treatments in the different rice cultivars and results presented in tables 2 . The results showed an increase in the activity of SOD with increased levels of Cd concentrations when compared with control for all cultivars. In every increased Cd level, SOD activity was higher compared to control. For Meixiangzhan 2 cultivar, when rice was subjected to 50 and $100 \mathrm{mg} / \mathrm{kg}$ Cd toxicity, there was a steadily increase in SOD activities of 9.39 and 25.77 for roots, and 4.75and13.04 for shoots respectively. For Xiangyaxiangzhan cultivar, the increase was 16.31 and28.04for roots and 15.85 and 27.75 for shoots respectively. While for Guixiangzhan cultivar, there was a 23.71 and 33.56 for roots and 30.52 and 40.27 for shoots increase respectively.

POD activity for each treatment in all cultivars were determined in both roots and leaves, the results showed a decrease in the activity of POD with increased levels of Cd concentrations when compared with control. In every increased Cd level, POD activity was lower compared to control. For Meixiangzhan 2 cultivar, when rice was subjected to 50 and $100 \mathrm{mg} / \mathrm{kg} \mathrm{Cd}$ toxicity, there was a steadily decrease in POD activities of 11.30 and $24.67 \%$ for roots and,12.16 and $19.36 \%$ for leaves respectively. For Xiangyaxiangzhan cultivar, the decrease was 7.06 and $21.54 \%$ for roots and, 0.38 and $15.82 \%$ for shoots respectively. While for Guixiangzhan cultivar, there was a 4.17 and 16.54 for roots and, 7.83 and 19.03 for shoots decrease respectively.

Significant increases were observed in CAT activity with increased Cd toxicity, but at certain toxic level, CAT activities were found reducing. When the increasing CAT activity was compared with Control for all cultivars, CAT activity in Meixiangzhan 2 cultivar subjected to 50 and $100 \mathrm{mg} / \mathrm{kg}$ Cd toxicity saw a steadily increase of 36.71 and 30.81 for roots, and 44.47 and36.12 for shoots respectively. For Xiangyaxiangzhan cultivar, the increase was 10.45 and $31.83 \%$ and, 22.84 and27.4\% respectively at $50 \mathrm{mg} / \mathrm{kg}$ Cd toxicity and then decreased at $100 \mathrm{mg} / \mathrm{kg} \mathrm{Cd}$ toxicity. While for Guixiangzhan cultivar, there was a 46.86 and $30.99 \%$ and,7.37 and $36.65 \%$ increase in roots and shoots respectively for the $50 \mathrm{mg} / \mathrm{kg}$ Cd toxicity, and then found decreased at $100 \mathrm{mg} / \mathrm{kg}$ Cd toxicity. Increased Cd concentrations caused an increased CAT activity.

Increased contents of lipid peroxides observed showed more production of toxic oxygen species. $\mathrm{Cd}$ toxicity showed significant increase in MDA production for all cultivars with increased $\mathrm{Cd}$ toxicity. In Meixiangzhan 2, Leaves showed higher MDA content compared to roots. In roots, when subjected to 50 and $100 \mathrm{mg} / \mathrm{kg}$ Cd toxicity, there was a 37.19 and 43.75 increase in roots MDA contents compared to control while in leaves, there was a 29.125 and 48.45 increase. In Xiangyaxiangzhan, when subjected to 50 and $100 \mathrm{mg} / \mathrm{kg} \mathrm{Cd}$ toxicity, there was a 18.74 and27.26 increase in roots MDA contents compared to control, while in leaves, there was a 13.64 and26.7increase. In Guixiangzhan, when subjected to 50 and $100 \mathrm{mg} / \mathrm{kg} \mathrm{Cd}$ toxicity, there was a 23.78 and8.67 increase in roots MDA contents compared to control, while in leaves, there was a 12.00 and21.93 increase. When rice grows under stressed conditions, free radicals generated in excess do accumulate in the cells, this leads to lipid peroxidation of bio membranes which forms MDA as end product. Hence, increase in MDA concentration is an indicator of physiological stresses and the aging process (Chen et.al. 2003).

Table 2.Cadmium effects on antioxidant enzymes and MDA in rice roots and shoots

\begin{tabular}{|c|c|c|c|c|c|c|c|c|c|}
\hline Variety & Treatments & \multicolumn{2}{|c|}{ SOD (U/gfw) } & \multicolumn{2}{|c|}{ POD(U/g.min) } & \multicolumn{2}{|c|}{ CAT(U/(g.min)) } & \multicolumn{2}{|c|}{$\operatorname{MDA}(\mu \mathrm{mol} / \mathrm{g})$} \\
\hline \multirow[t]{2}{*}{ Meixiangzhan 2} & $\mathrm{Cd} 0$ & Roots & Stem & Roots & Stem & Roots & stem & Roots & stem \\
\hline & $\mathrm{Cd} 1$ & $71.00 \mathrm{~b}$ & $49.00 \mathrm{a}$ & $185.67 \mathrm{~b}$ & $65.00 \mathrm{~b}$ & $371.33 \mathrm{a}$ & $247.33 \mathrm{a}$ & $14.33 \mathrm{a}$ & $8.00 \mathrm{~b}$ \\
\hline \multirow{3}{*}{ Xiangyaxiangzhan } & $\mathrm{CdO}$ & $65.00 \mathrm{c}$ & $46.00 \mathrm{c}$ & $237.50 \mathrm{a}$ & $86.33 \mathrm{a}$ & $237.00 \mathrm{c}$ & $168.67 \mathrm{c}$ & $8.67 \mathrm{c}$ & $6.33 \mathrm{~b}$ \\
\hline & $\mathrm{Cd} 1$ & $77.67 \mathrm{~b}$ & $54.67 \mathrm{~b}$ & $220.67 \mathrm{a}$ & $86.00 \mathrm{a}$ & $379.33 \mathrm{a}$ & $278.67 \mathrm{a}$ & $10.67 \mathrm{~b}$ & $7.33 \mathrm{ab}$ \\
\hline & $\mathrm{Cd} 2$ & $90.33 a$ & $63.67 \mathrm{a}$ & $186.33 b$ & $72.67 \mathrm{a}$ & $347.67 \mathrm{~b}$ & $232.33 \mathrm{~b}$ & $14.67 \mathrm{a}$ & $10.00 \mathrm{a}$ \\
\hline \multirow[t]{2}{*}{ Guixiangzhan } & $\mathrm{Cd} 1$ & $84.33 b$ & $63.33 \mathrm{~b}$ & $222 b$ & $82.33 \mathrm{a}$ & $239.00 \mathrm{a}$ & $140.00 \mathrm{~b}$ & $14.00 \mathrm{a}$ & $8.33 \mathrm{~b}$ \\
\hline & $\mathrm{Cd} 2$ & $97.00 \mathrm{a}$ & $73.67 \mathrm{a}$ & $193.33 c$ & $72.33 \mathrm{~b}$ & $346.33 \mathrm{a}$ & $221.00 \mathrm{a}$ & $15.33 \mathrm{a}$ & $10.67 \mathrm{a}$ \\
\hline
\end{tabular}

Means having different letters indicate significant differences at $p<0.05$

Cd concentration in rice roots and straw at harvest $(\mathrm{ug} / \mathrm{g})$

Cd uptake and accumulation in various plants parts (roots and shoots) of the three rice genotypes used in the experiment were detected and results shown in Table 3. In all cultivars, $\mathrm{Cd}$ accumulation in the various organs (roots and shoots) was found elevated with increased concentrations of soil Cd contents. In average, $\mathrm{Cd}$ 
accumulation was in the descending order: root>straw for all the $\mathrm{Cd}$ treatments in all cultivars. The concentration of $\mathrm{Cd}$ in various rice organs (root>straw) were significantly different among the three aromatic rice varieties as shown in table 3 above. In terms of uptake, there were outstanding differences in Cd uptake between the different rice organs especially from roots to stems, Guixiangzhan showed the least uptake in both roots and shoot for all treatments followed by Xiangyaxiangzhan while Meixiangzhan showed the highest uptake. Variation in transfer factors from roots to shoots were also observed and were found maximum in Meixiangzhan followed by Xiangyaxiangzhan while Guixiangzhan showed the least for all treatments.

Table 3CdUptake in Rice Roots and Straw at Harvest (ug/g)

\begin{tabular}{|l|l|l|l|l|l|}
\hline Variety & Treatments & Roots & Straw & whole plant & R-S Transfer factor \\
\hline Meixiangzhan 2 & $\mathrm{Cd} 0$ & $8.25 \mathrm{c}$ & $1.98 \mathrm{c}$ & 10.23 & 0.24 \\
\cline { 2 - 6 } & $\mathrm{Cd} 1$ & $197.01 \mathrm{~b}$ & $11.09 \mathrm{~b}$ & 208.09 & 0.056 \\
\cline { 2 - 6 } & $\mathrm{Cd} 2$ & $241.40 \mathrm{a}$ & $16.74 \mathrm{a}$ & 258.139 & 0.069 \\
\hline \multirow{5}{*}{ Xiangyaxiangzhan } & $\mathrm{Cd} 0$ & $5.66 \mathrm{c}$ & $1.84 \mathrm{c}$ & 7.5 & 0.32 \\
\cline { 2 - 6 } & $\mathrm{Cd} 1$ & $141.89 \mathrm{~b}$ & $10.02 \mathrm{~b}$ & 151.91 & 0.07 \\
\cline { 2 - 6 } & $\mathrm{Cd} 2$ & $185.21 \mathrm{a}$ & $16.55 \mathrm{a}$ & 201.76 & 0.09 \\
\hline \multirow{5}{*}{ Guixiangzhan } & $\mathrm{Cd} 0$ & $4.52 \mathrm{c}$ & $1.79 \mathrm{c}$ & 6.31 & 0.39 \\
\cline { 2 - 6 } & $\mathrm{Cd} 1$ & $84.93 \mathrm{~b}$ & $6.61 \mathrm{~b}$ & 91.54 & 0.07 \\
\cline { 2 - 5 } & $\mathrm{Cd} 2$ & $117.85 \mathrm{a}$ & $9.46 \mathrm{a}$ & 127.31 & 0.08 \\
\hline
\end{tabular}

Means having different letters indicate significant differences at $p<0.05$

\section{Growth Parameters}

Rice plants height, shoots and roots dry weight for the different treatments in all cultivars were determined after the rice plants were all harvest (after 45 days vegetative growth period) and the results presented in table 4. Rice plants height, shoot and root dry weights were maximum at control treatments for all cultivars and Guixiangzhanshowed the highest height and dry weights contents, while the minimum plants height, root and shoot dry weight was recorded at $100 \mathrm{mg} \mathrm{kg}^{-1}$ cadmium levels for all the cultivars and Meixiangzhan 2 showed the least in terms of height and dry weights. Maximum to minimum plants height, shoots and roots dry weight for the different treatments in all cultivars were in the order Guixiangzhan>Xiangyaxiangzhan>Meixiangzhan 2.

Table 4. Growth parameters

\begin{tabular}{|l|l|l|l|l|}
\hline Variety & Treatment & plant height $\left(\mathrm{cm}\right.$ plant $\left.{ }^{-1}\right)$ & SHOOT DRY WEIGHT (g/hill) & ROOTS DRY WEIGHT (g/hill) \\
\hline \multirow{5}{*}{ Meixiangzhan 2 } & $\mathrm{Cd} 0$ & $38.67 \mathrm{a}$ & $3.00 \mathrm{a}$ & $1.50 \mathrm{a}$ \\
\cline { 2 - 5 } & $\mathrm{Cd} 1$ & $35.33 \mathrm{~b}$ & $2.50 \mathrm{~b}$ & $1.30 \mathrm{a}$ \\
\cline { 2 - 5 } & $\mathrm{Cd} 2$ & $32.00 \mathrm{c}$ & $1.73 \mathrm{c}$ & $0.97 \mathrm{~b}$ \\
\hline \multirow{5}{*}{ Xiangyaxiangzhan } & $\mathrm{Cd} 0$ & $41.00 \mathrm{a}$ & $3.27 \mathrm{a}$ & $1.57 \mathrm{a}$ \\
\cline { 2 - 5 } & $\mathrm{Cd} 1$ & $36.00 \mathrm{~b}$ & $2.73 \mathrm{~b}$ & $1.10 \mathrm{~b}$ \\
\cline { 2 - 5 } & $\mathrm{Cd} 2$ & $34.00 \mathrm{c}$ & $1.50 \mathrm{c}$ & $0.97 \mathrm{~b}$ \\
\hline \multirow{5}{*}{ GUIXIANGZHAN } & $\mathrm{Cd} 0$ & $47.33 \mathrm{a}$ & $3.80 \mathrm{a}$ & $1.77 \mathrm{a}$ \\
\cline { 2 - 5 } & $\mathrm{Cd} 1$ & $46.67 \mathrm{a}$ & $3.63 \mathrm{a}$ & $1.73 \mathrm{a}$ \\
\cline { 2 - 5 } & $\mathrm{Cd} 2$ & $44.67 \mathrm{~b}$ & $3.30 \mathrm{~b}$ & $1.50 \mathrm{~b}$ \\
\hline
\end{tabular}

Means having different letters indicate significant differences at $p<0.05$

\section{Discussions}

Antioxidants enzymes play a very vital role in plants defence mechanisms. Abiotic stresses like heavy metals especially $\mathrm{Cd}$ results to molecular damage in rice plant cells due to the generation of reactive oxygen species (ROS) (Hegedus., 2004). Even though Cd by itself does not directly generate ROS, but rather generates oxidative stress by interrupting essential antioxidant defencesystem. Antioxidant enzymes balance the production and destruction of ROS. In our experiment, the activities of catalase, peroxidase and superoxide dismutase were measured as antioxidant enzymes and the results showed a significant different in the means of the different treatments for all cultivars. Our study revealed that the activities of SOD in the root and straw for all the cultivars increased at low soil Cd levels (Table 2). The increase in SOD activity can be attribute to Cdinduced phytotoxicity as concluded by Hou and $\mathrm{Kao}(2007)$, this acts as an adaptive response means of plants exposed to heavy metals toxicity (Camp, 1996). However, our findings reveal that SOD activity decreased with increased soil $\mathrm{Cd}$ level, suggesting that the high soil $\mathrm{Cd}$ level might have damaged the antioxidant defencesystem by reducing SOD activity in the rice roots and straw. The decline in POD and CAT activities with increased soil Cd levels was observed in all cultivars. It revealed that antioxidant enzymes like SOD, POD and CAT work in coordination to minimize oxidative stress in rice plants during growth. In summary, the activities of SOD, POD and CAT in both roots and straw showed significant differences between rice treatments as well as cultivars after exposure to $\mathrm{Cd}$ toxicity. 
Oxidative stress in rice plant as a result of contamination by toxic metals can be manifested in the activity of MDA, which is a significant indicator of lipid peroxidation (Chaouiet al., 1997). Results from our study showed significant increases in MDA contents in all cultivars after exposed to Cd toxicity (Table 2), this increase indicated toxic effects in rice roots and straw.

Less changes in MDA content was observed in Guixiangzhan and Xiangyaxiangzhan when compared to the other two varieties subjected under the same $\mathrm{Cd}$ treatment. This indicates that lipid peroxidation was higher in Meixiangzhan 2 than that in Guixiangzhan and Xiangyaxiangzhan,this is possibly due to the higher uptake ability of $\mathrm{Cd}$ in Meixiangzhan 2 cultivar compared to Guixiangzhan and Xiangyaxiangzhan. Decline in biochemical content (Proline, protein, amino acid and total sugar)with increased Cd levels also suggested a strong induction of oxidative stress.

Cadmium concentrations in straw and root of all cultivars significantly increased withincreased levels (Table ). Cadmium contents in roots and strawwere higher in Meixiangzhan 2 than that in Guixiangzhan and Xiangyaxiangzhan for all treatments, this wasprobably as a result of the higher uptake and translocation ability of Cd from the soil medium to roots and then to straw. The differences observed in accumulation may be related to the genotypic tolerance nature of the cultivars to cadmium toxicity. Genotypic variations of $\mathrm{Cd}$ tolerance in rice cultivars were reported by Liu et al. (2005). Cadmium uptake and translocation from contaminated soil to plants edible parts were markedly different among plant species as well as cultivars within the same species (Liu et al. 2007). In our study, differences in Cd uptake between cultivars were observed, this might be as a result of roots oxidation ability, roots organic acid secretions and roots acidification (Liu et al. 2007).

\section{Conclusions}

Result from this study has shown that, cadmium toxicity in growing rice seedlings impeded morphophysiological and antioxidants activities in rice during early growth. Cd toxicity damages the antioxidant defence system resulting to oxidative stress in organs of growing rice plants, this resulted to alteration inAntioxidant enzymes (Superoxide dismutase (SOD), Peroxidase(POD), and Catalase(CAT)), osmolyte accumulation (proline, protein, total sugar, amino acid), lipid peroxidation (in terms of melanodialdehydeMDA) and growth parameters (plant height, and total dry matter content). At $100 \mathrm{mg} / \mathrm{kg}$ soil Cd toxicity, growing rice seedlings become critical and vulnerable to toxicity. The results suggested that soil Cd toxicity have negative consequences on rice growth. Rice roots accumulated higher $\mathrm{Cd}$ than shoots and uptake varies amongst cultivars. Conclusively, Cd toxicity impaired early growth in rice by affecting physio-biochemical attributes, however, Guixiangzhan variety performed better than the other two varieties.

\section{Acknowledgement}

This work was supported by China's Natural Science Foundation (31271646), Guangdong Province Natural ScienceFoundation(8151064201000017), Guangdong Province Agricultural Research Projects(2011AO20202001) and the Guangdong Province Agricultural Standardization Project (4100 F10003).

\section{References}

[1]. A. Chaoui, S. Mazhoudi, M.H. Ghorbal, E. E. Ferjani. Cadmium and zinc induction of lipid peroxidation and effects on antioxidant enzyme activities in bean (Phaseolusvulgaris L.). Plant Science, (1997)127: 139-147.

[2]. A. Hegedus, S. Erdei, T. Janda, E. Toth, G. Horvath, D. Dubits. Transgenic tobacco plants over producing alfafa aldose/aldehyde reductase show higher tolerance to low temperature and Cadmium stress. Plant Sci. (2004); 166:1329-33.

[3]. A. Sebastian, M. N. V. Prasad. Operative photo assimilation associated proteome modulations are critical for iron-dependent cadmium tolerance in Oryzasativa L. Protoplasma (2015) 252:1375-1386

[4]. C .A .Grant, J. M Clarke, S.Duguid, R. L. Chaney. Selection and breeding of plant cultivarsto minimize cadmium accumulation. Science of the Total Environment, (2008). 390, 301-310.

[5]. F.Douay, C.Pruvot,C. Waterlot, C.Fritsch, H. Fourrier, A.Loriette,G. Bidar, C. Grand, A. de Vaufleury, R. Scheifler,Contamination of woody habitat soils around a former lead smelter inthe North of France. Science of the Total Environment (2009) 407(21): 5564 $-5577$

[6]. F.Yu, K. Liu, M. Li, Z. Zhou, H. Deng, B. Chen. Effects of cadmium on enzymatic and nonenzymaticantioxidative defences of rice Oryzasativa L. Int J Phytoremediation (2013) 15:513-521

[7]. J. G. Liu, Q. S. Zhu, Z. J. Zhang, J. K. Xu, J. C. Yang, M. H. Wong. Variations in cadmium accumulation among rice cultivars and types and the selection of cultivars for reducing cadmium in the diet. Journal of the Science ofFood and Agriculture, (2005). 85: $147-153$.

[8]. J. Liu, M. Qian, G. Cai, J.Yang, Q. Zhu. Uptake and translocation of Cd in different rice cultivars and the relation with Cd accumulation in rice grain. Journal of Hazardous Materials, (2007). 143, 443-447

[9]. M. Rizwan, J.D. Meunier, H. Miche, C. Keller. Effect of silicon on reducing cadmium toxicity in durum wheat (Triticumturgidum L. cv. Claudio W.) grown in a soil with aged contamination. J Hazard Mater (2012) 209-210:326-334

[10]. M. Rizwan, S. Ali, M. Adrees, H. Rizvi, M. Z. Rehman, F. Hannan, M. F. Qayyum, F. Hafeez, Y. S. OK. Cadmium stress in rice: toxic effects, tolerance mechanisms and management: A critical review. Environ. Sci. Pollut. (2016). Res. http: //dx.doi.org/10.1007/s11356-016-6436-4

[11]. P. Römkens, D. J. Brus, H. Y. Guo, C. L. Chu, C. M. Chiang, G. F. Koopmans. Impact of model uncertainty on soil quality standards for cadmium in rice paddy fields. Science of the Total Environment, (2011). 409, 3098-3105. 
[12]. R. K. Srivastava, P. Pandey, R. Rajpoot, A. Rani, R. S. Dubey. Cadmium and lead interactive effects on oxidative stress and antioxidative responses in rice seedlings. Protoplasma (2014). 251:1047-1065

[13]. U. Ashraf, A. S. Kanu, Z. Mo, S. Hussain, S. A. Anjum, I. Khan, R. N. Abbas, X. Tang. Lead toxicity in rice: effects, mechanisms, and mitigation strategies-a mini review. Environ Sci. Pollut. Res. (2015)22:18318-18332. doi: 10.1007/s11356-015-5463-x

[14]. W.E.Song, S. B. Chen, J. F. Liu, C. H. Li, N. N. Song, L. I. Ning, L. I. Bin. Variation of Cd concentration in various rice cultivars and derivation of cadmium toxicity thresholds for paddy soil by species-sensitivity distribution. J IntegAgri (2015) 14:1845-1854

[15]. W.V. Camp, K. C.Capiau,M. V. Van Montagu, D.Inz'e, L. Slooten. Enhancement or oxidative stress tolerance intransgenic tobacco plants overproducing Fe-superoxide dismutase in chloroplasts. Plant Physiology, (1996)112: 1703-1714.

[16]. X. Xu, Y. Zhao, X. Zhao, Y.Wang, W. Deng. Sources of heavy metal pollution in agricultural soils of a rapidly industrializing area in the Yangtze Delta of China. Ecotoxicology and Environmental Safety, (2014). 108, 161-167.

[17]. Y. T. Hou, C. H. Kao. Cadmium-induced oxidative damage in rice straw is reduced by polyamines. Plant and Soil, (2007) 291:2737.

[18]. Y. X. Chen, Y. F. He, Y. M. Luo, Y. L.Yu, Q. Lin, M. H. Wong. Physiological mechanism of plant roots exposed to cadmium. Chemosphere. (2003);50:789-93. 